\title{
PERIPHERAL NEUROPATHY IN HYPEREOSINOPHILIC SYNDROME WITH VASCULITIS
}

\author{
OSVALDO NASCIMENTO* - MARCOS DE FREITAS* - LEILA CHIMELLI ** \\ FRANCESCO SCARAVILLI ***
}

\begin{abstract}
SUMMARY - A 53-year-old woman with non-productive cough of unexplained aetiology for two years, developed a sub-acute symmetrical polyneuropathy involving all four limbs, accompanied by fever, cutaneous rash and myalgia in lower limbs. Laboratory studies revealed a leukocytosis with $70 \%$ eosinophils and excluded any cause for the hypereosinophilia. An echocardiogram showed increase in thickness of the atrial septum. Motor and sensory conduction velocity were reduced in ulnar and median nerve, and unrecordable in peroneal and tibial nerves. A sural nerve biopsy showed an axonal degeneration involving myelinated and unmyelinated fibers as well as a vasculitis with fibrinoid necrosis and perivascular infiltration of eosinophils. There was considerable clinical and laboratorial improvement with the use of steroids. The differential diagnosis between idiopathic hypereosinophilic syndrome and other disorders known to course with vasculitis and hypereosinophilia is discussed.
\end{abstract}

Neuropatía periférica na síndrome hipereosinofílica com vasciilite

RESUMO - Urna paciente de 53 anos de idade com tosse não produtiva de etiologia inexplicada durante dois anos desenvolveu polineuropatia subaguda envolvendo os quatro membros, acompanhada de febre, erupção cutânea e mialgia nos membros inferiores. Os estudos laboratoriais revelaram leucocitose com $70 \%$ de eosinófilos e excluíram qualquer causa para esta hipereosinofiliia. Um ecocardiograma mostrou aumento da espessura do septo atrial. As velocidades de condução motora e sensitiva estavam reduzidas nos nervos ulnar e mediano e não foram registradas nos nervos tibial e fibular. A biópsia do nervo sural mostrou degeneração axonal envolvendo fibras mielínicas e ¡amielínicas, assim como vasculite com necrose fibrinóide e infiltração perivascular de eosinófilos. Ocorreu considerável melhora com o uso de esteróide. O diagnóstico diferencial entre. »a síndrome hipereosinofílica idiopática e outras afecções que cursam com vasculite e hipereosinofilia é comentado.

Hypereosinophilia is commonly associated with parasitic infections and allergic diseases 5,9,20 Hodgkin's disease and other malignancies 9,19, systemic vasculitis fibroblastic endocarditis ${ }^{\wedge}$, allergic granulomatosis or Churg-Strauss syndrome3, polyarteritis nodosa 5, eosinophilic leukemia ${ }^{4}$, sarcoidosis 9 or may represent a reaction to several drugs 9. In the absence of a known aetiology for the hypereosinophilia and when it is associated with organs injuries, it has been termed idiopathic hypereosinophilic syndrome (HES) 5,9,12. in this condition, the organ more frequently involved is the heart which shows endomyocardial fibrosis. However other organs such as skin, lungs, spleen, liver as well as the nervous system may also be affected 5.

Involvement of the central and peripheral nervous system has been reported $5,6,9,16,18,20,24$, the peripheral neuropathy appearing as polyneuropathy 9,18 and mononeuritis multiplex 6,18. We present the clinical, electrodiagnostical and pathological findings in a patient who developed a hypereosinophilic syndrome and associated peripheral neuropathy.

* Department of Clinical Medicine (Neurology), ** Department of Pathology (Neuropathology), Hospital Universitário Antonio Pedro, Universidade Federal Fluminense, Rio de Janeiro, Brazil; *** Department of Neuropathology, Institute of Neurology, London, England.
Dr. Osvaldo
M. Nascimento - Rua Mal. Ramo
Castilla
$251 / 903$
22290 Rio de Janeiro

RJ - Brasil. 


\section{CASE REPORT}

TMM, a 53-year-old woman developed nonproductive cough of unexplained aetiology for two years. She was admitted to hospital with fever, subacute onset of stabbing pains in all limbs, numbness, paresthesia and symmetrical weakness of the distal parts of both legs and arms. Disseminated petechial rash was observed in the four limbs and trunk which disappeared spontaneously within 10 days. At the same time she experienced difficulty in walking. Neurological examination showed no signs referable to central nervous system dysfunction; there was grade $3 / 5$ weakness of the distal part of the upper limbs, particularly the intrinsic hand muscles and grade $4 / 5$ weakness in the legs; the deep tendon reflexes were absent in all four limbs; temperature, touch and pin sensation were decreased especially distally and vibration sense was diminished from the toes to the knees. Within a few weeks atrophy of the thenar, hypo thenar regions and interossei muscles in both hands became apparent. Laboratory studies revealed a total leukocyte count of $2700 \mathrm{Omm} 3$ with $70 \%$ eosinophils; chest X-ray showed slight interstitial infiltrates; normal or negative laboratory findings included sedimentation rate, fluorescent anti-nuclear antibodies, serum complement, cryoglobulins, creatine kinase, tests for parasites, rheumatoid factor titer, antibodies anti-DNA, IgE (150U) and CSF examination; a bone marrow aspirate biopsy showed 50\% eosinophils. Echocardiogram showed increase in thickness of the atrial septum. Ultrasound of the abdomen revealed slightly enlarged liver and normal spleen. Electrodiagnostic studies revealed decreased motor and sensory conduction velocity (CV) in the ulnar and median nerves, being lower in the left median nerve, with increase of the distal latency; peroneal and tibial neives $\mathrm{CV}$ could not be recorded; concentric needle electromyography demonstrated active denervation in almost all tested arm and leg muscles.

A whole biopsy of the left sural nerve was performed three weeks after the onset of the neuropathy. The nerve was divided into small fragments for paraffin embedding, teased fiber preparations and Araldite embedding. Fragments for light microscopic studies were fixed in 10\% formalin; sections were stained with hematoxilin and eosin, phosphotungstic hematoxilin and luxol fast blue. Fragments for plastic embedding and teasing were fixed in $2.5 \%$ glutaraldehyde $(\mathrm{pH} 7.4)$ for $24 \mathrm{~h}$ at 4 ? C, post-fixed in $1 \%$ osmium tetroxide, dehydrated in graded alcohols cleared in propilene oxide and embedded in Araldite. One um-thick sections were stained with toluidine blue and ultra-thin sections with uranyl acetate and lead citrate. Paraffin sections revealed, after serial sections, medium-sized epineurial vessels

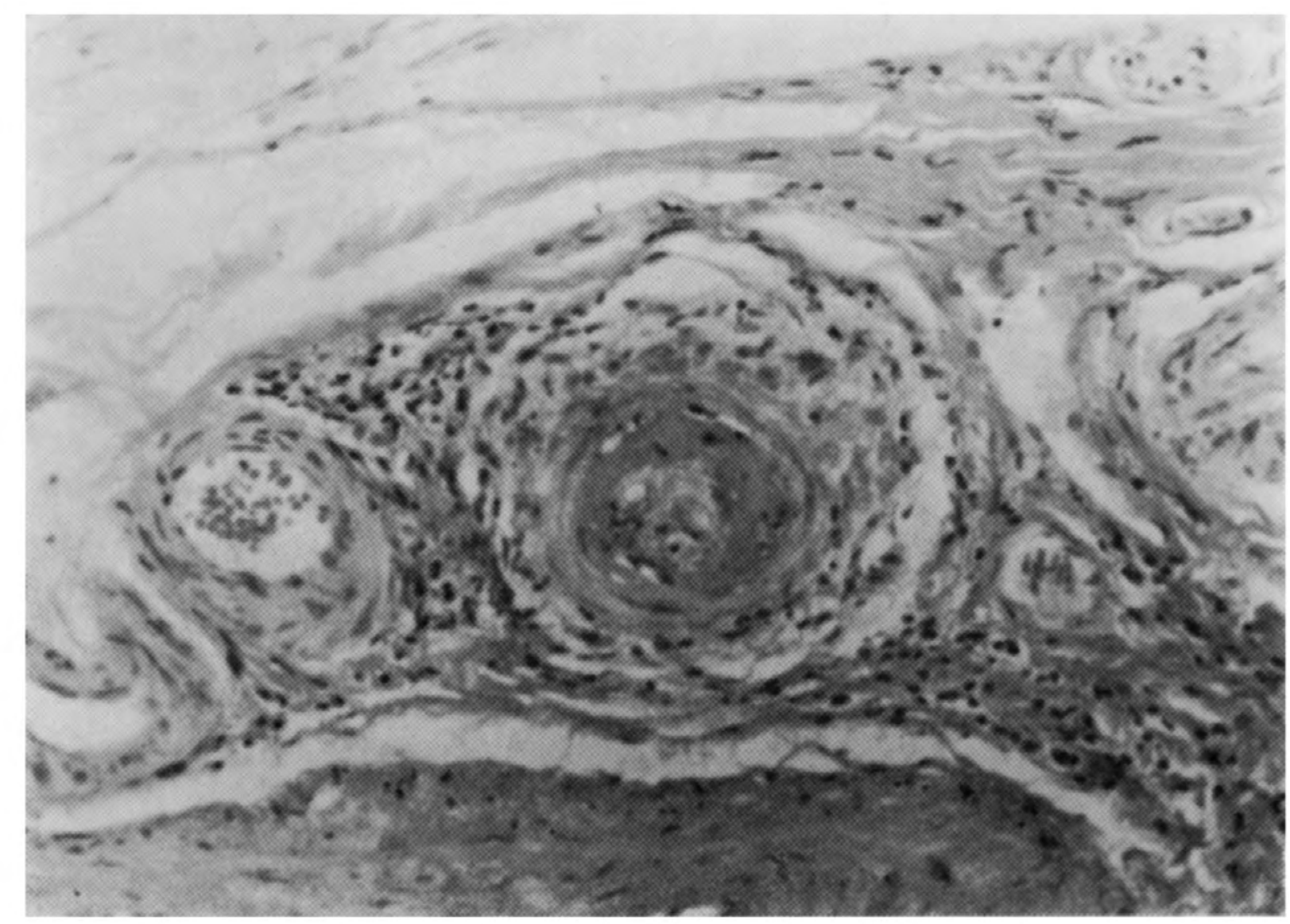

Fig. 1 - Paraffin section showing an epineural vessel with fibrinoid necrosis of the thickened wall and perivascular inflammatory infiltrate. $H \& E$ neg $\times 100$. 
with thickened walls infiltrated by small cells and showing areas of fibrinoid necrosis (Fig. 1) and intimal proliferation, which in areas almost occluded the lumen; inflammatory infiltrates consisted of mononuclear cells and eosinophils; eosinophilic infiltration of epineurial perivascular connective tissue and fat was also seen and the blood vessels in these regions were congested and contained many eosinophils; some endoneurial small vessel walls were also thickened, occasionally infiltrated by eosinophils which were also seen scattered in the en-

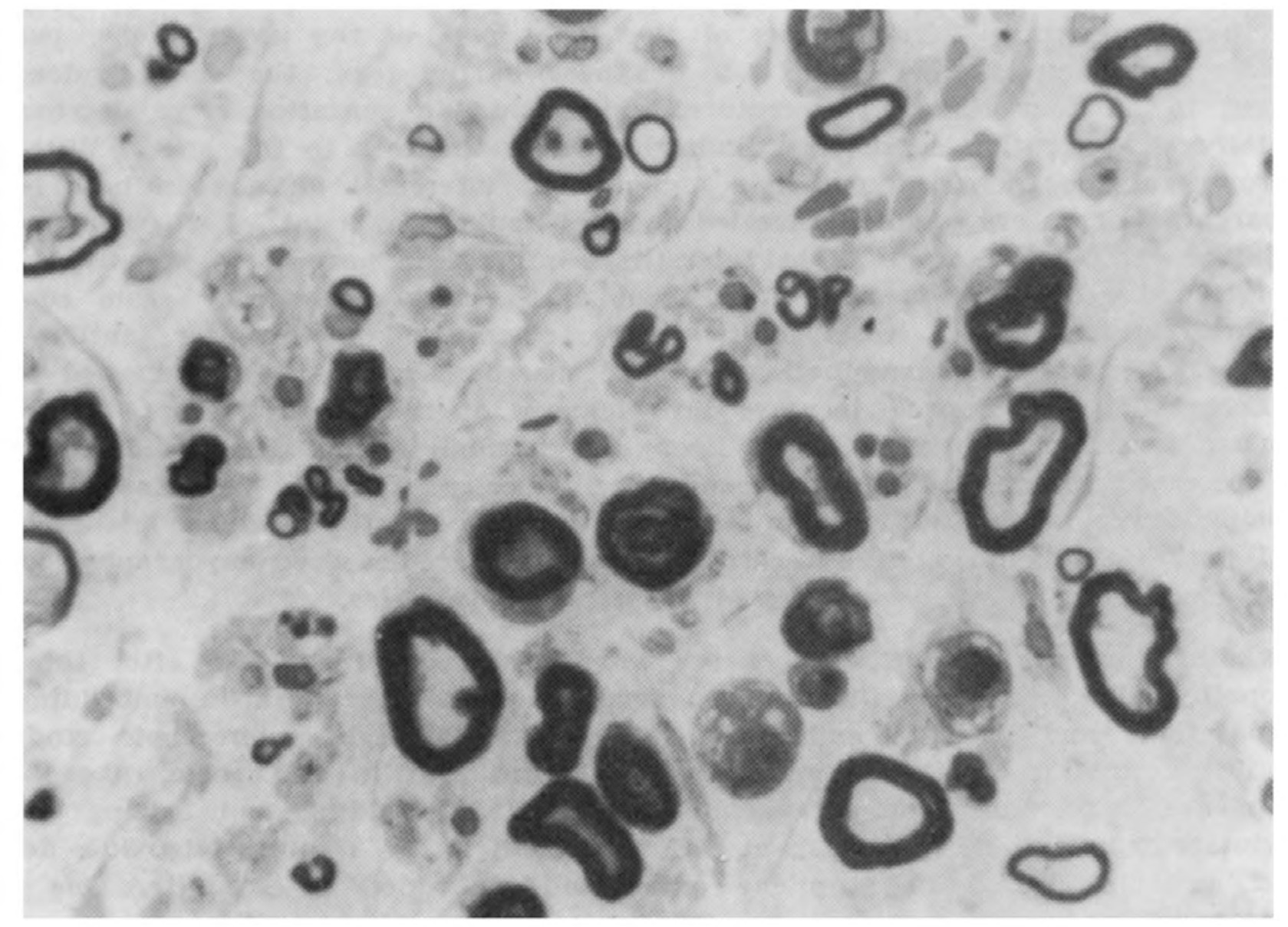

Fig. 2 - Semithin Araldite section showing several myelinated fibers undergoing axonal degeneration. Toluidine blue neg $\times 400$.

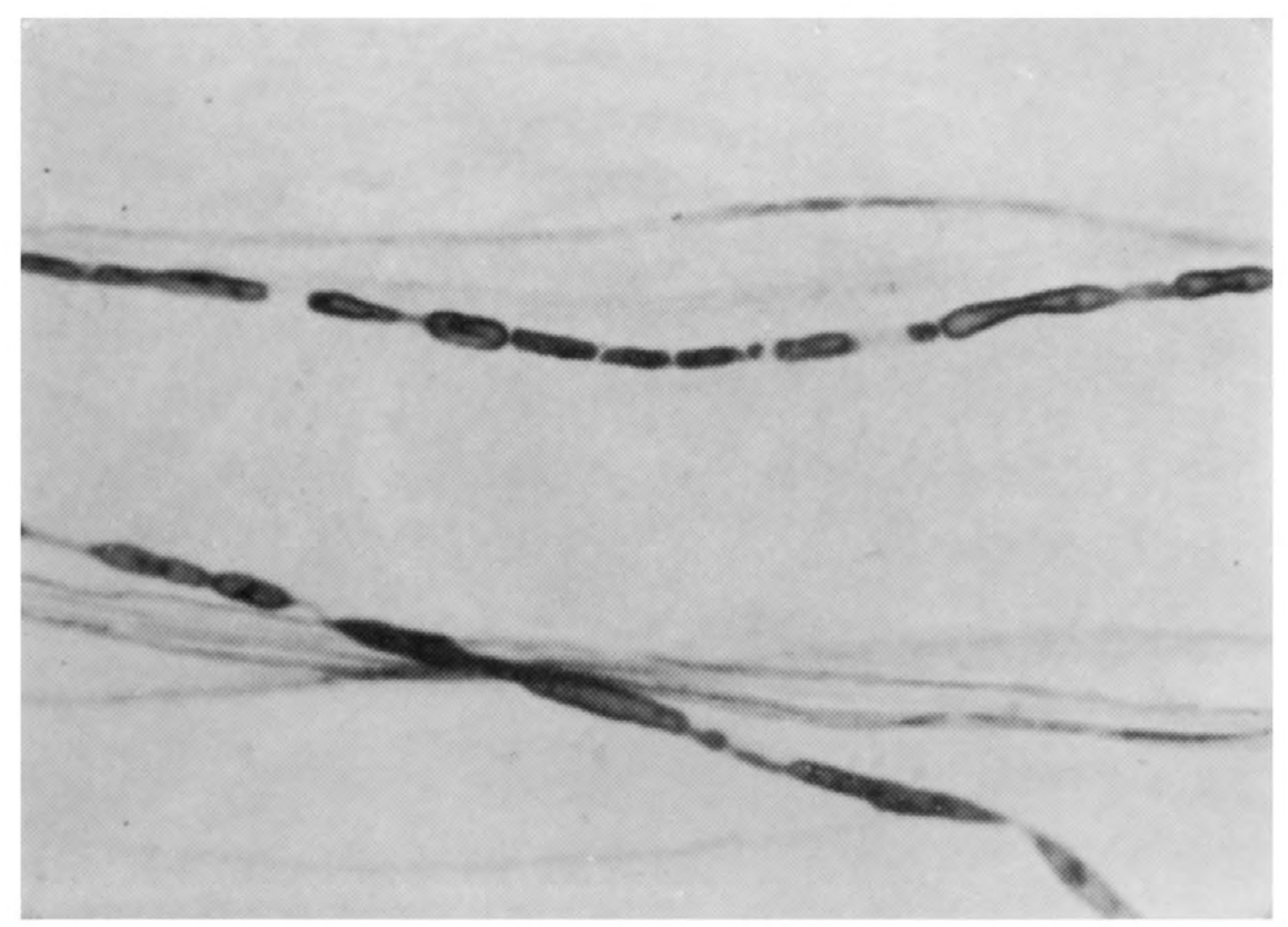

Fig. 3 - Teased fibers showing myelin ovoids secondary to axonal degeneration. Neg $\times 100$. 
doneurium. Semithln sections showed many axons undergoing degeneration (Fig. 2) with occasional myelin breakdown and some macrophages containing myelin debris. These findings were confirmed in teased fiber preparations which showed typical features of waller!an degeneration with myelin ovoids (Fig. 3) and with electronmicroscopy where there were signs of axonal degeneration in myelinated and unmyelinated fibers. Myelin sheaths were usually intact; some cells present in the perineurium where shown to be eosinophils with their typical cytoplasmic granules.

Massive doses of methyl prednisolone during the first three weeks (1.5g/day) followed by a daily dose of $60 \mathrm{mg}$ of prednisone produced a marked improvement in neurological symptoms and decrease in eosinophilic count. Increase in the steroid dose produced prompt effect when the eosinophilia was increased. The patient is now being controlled with $20 \mathrm{mg}$ of prednisone.

\section{COMMENTS}

This patient presented a symmetrical polyneuropathy during the course of a systemic disorder characterized by marked increase of circulating eosinophils. A clinical diagnosis of idiopathic HES was based on the exclusion of other known causes of persistent eosinophilia 5,9. Laboratory data did not suggest a mixed connective tissue disease or collagen vascular disorder, nor a hematological disease or other malignancy and multiple tests for parasitic infections were negative. Drug or medicine induced neuropathy were rulled out. As for the type of nerve injury the lesions observed in our case is in agreement with most of the reported cases in which it was shown morphologically that the primary event seems to be an axonal degeneration 6,14,22,24 although Weaver et al. ${ }^{22}$ found evidence of segmental demyehnation. An axonal neuropathy was also demonstrated electrophysiologically by Wichman et al. $^{24}$ and Monaco et al. ${ }^{\wedge}$.

The role of the eosinophil in the production of axonal damage is not clear. Eosinophil derived toxins have been reported as the possible cause of neuropathy ${ }^{24}$ Another pathogenetic mechanism involves eosinophil-induced injury to blood vessels which could explain the lesions observed in the hearts and ultrastructural findings indicate that the primary site of damage is the endocardium and the endothelium of the intramural cardiac microvasculature. The damaged vascular endothelium incites local thrombosis, and recurrent cycles of damage, thrombosis, and organization of thrombi lead eventually to the characteristic cardiac lesions. A similar mechanism could readily account for the peripheral nerve lesions described here, although definite evidence of microvascular damage and thrombosis were not evident in the biopsy specimen. Spry et al.20 in 15 cases postulated a thromboembolic mechanism for the visceral, retinal and CNS lesions, although they had not observed peripheral neuropathy. Binaghi et al. ${ }^{2}$ postulated a thromboembolic mechanism for the retinal involvement in HES. Monaco et al. $^{\prime}{ }^{\wedge}$ suggested that the axonal damage is secondary to increased endoneurial pressure from leakage of capillaries. They postulate that endothelial cell damage, followed by nerve edema is the first step in the pathogenesis of peripheral neuropathy in these patients.

On the basis of clinical, electrophysiological and morphological findings, the polyneuropathy presented by our patient could not be distinguished from that seen in patients with vasculitis $7,21,23$, which in fact existed in the present case and was the cause of the axonal damage which was therefore ischemic in origin. However, in the presence of vasculitis, the diagnosis of idiopathic HES had to be reconsidered. According to Wichman et al. ${ }^{24}$ and Monaco et al.is vasculitis is not present in idiopathic HES. Dorfman et al.6 would include alternative diagnosis such as polyarteritis nodosa (PAN) or Churg Strauss syndrome (CSS), had any of their patients demonstrated pathologic evidence of vasculitis; the authors did not rule out the possibility that in their cases vasculitis might have been present at more proximal sites. Chusid et al.5 did not discard the diagnosis of idiopathic HES in the presence of vasculitis (cases 4 and 8 ), although the possibility of CSS and atypical PAN respectively were considered in these two cases. On the other hand, vasculitis has been described in the retina ${ }^{2}$ without morphological demonstration, and in the skin biopsies\&»13 of patients with HES although fibrinoid necrosis has not been mentioned. Grisoldi and Jellinger 11 described a case with lymphomononuclear vasculitis of interstitial vasa nervorum without eosinophils. The patient died and autopsy disclosed vasculitis of epineurial vessels of peripheral nerves with rare fibrinoid necrosis and severe axonal 
neuropathy particularly of the lower limbs (but no generalised vasculitis). In their case, the morphological pattern of vasculitis did not resemble that of periarteritis nodosa, necrotizing vasculitis or granulomatous arteritis, but rather resembled the changes observed in drug-induced vasculitis; chromolyn sodium treatment was reported in their patient. In three patients described by Moore et al. ${ }^{18}$ a symmetrical sensory polyneuropathy was associated with a systemic vasculitis, showed by biopsy or angiogram even though they did not show evidence of vasculitis of the vasa nervorum.

According to Dorfman et al. $^{6}$ it is frequently difficult to distinguish clearly these conditions in which vasculitis and hypereosinophilia are present. Pulmonary involvement with interstitial infiltrates may be present in PAN 10,17, CSS 15,17 and idiopathic HES 5.6,9 although not so common in PAN 3.17 and usually with a history of asthma in CSS 3.15. Cardiac involvement is more frequently found in PAN io and in idiopathic HES, however this pattern of thickened atrium septum strongly suggests HES 5,9,20. $i_{n}$ PAN ischemic lesions are more frequently found 10 and in CSS the most common finding is a pericarditis 8. Skin lesions such as those present in our patient can be seen in all three conditions 3.9,10. The laboratory data did not suggest a connective tissue disease in our case.

Morphologically, the vasculitis found in our case can not be distinguished from that of PAN 10,15, although according to Moore and Cupps*?, perivascular eosinophils are generally not present in PAN. We did not find perivascular granulomas with giant cells seen in CSS, but there are reports of this disease without giant cells 3 . CSS affects not only medium sized but also small venules and capillaries ${ }^{3}$ as seen in our case.

Corticosteroid treatment improved the peripheral nerve symptoms and the eosinophilic count in our case as well as in the cases reported by Dorfman et al.6, Grisoldi and JellingerU, Weaver et al.22 $\mathbf{j}_{\mathrm{n}}$ one of two cases, Monaco et $\mathbf{a l}^{1{ }^{16}}$ in patients 1 and 2, Moore et al. ${ }^{18}$ in several patients.

In conclusion, although we have arguments to consider this case as an idiopathic HES, the finding of vasculitis makes the diagnosis not so certain, since many authors do not accept its presence in cases of idiopathic HES. As can be seen above the individualization of CSS and PAN is not always very clear and we find it difficult to situate our case in one of these disorders and even to label it as a purely idiopathic HES. It might also be possible that other cases described as idiopathic HES could in fact have a systemic vasculitis which has not appeared in the nerve biopsy. In our case for instance, it was only after the examination of serial sections of the nerve that we could detect the vasculitis.

Acknowledgements - The authors gratefully acknowledge Prof. P.K. Thomas who gave his valuable opinion about this case. We should like to thank Miss Ana Rodrigues and Rita de Cassia Costa Cunha for technical assistance and Rosely Costa Cunha for the photographic work.

\section{REFERENCES}

1. Binaghi M, Gaudric A, Farcet J-P, Coscas G. Artérite rétinienne bilatérale extensive au cours d'un syndrome hypereosinophilique chez un malade porteur d'ne tuberculose. Bull Soc Opht France, 1982, 82:59-63.

2. Binaghi M, Perrenoud F, Dhermy P, Coscas G. Syndrome hypereosinophilique avec atteinte oculaire. J Fr Ophtalmol 1985, $8: 309-314$.

3. Chumbley LC, Harrison EG Jr, DeRemee RA. Allergic granulomatosis and angiitis (Churg-Strauss syndrome): report and analysis of 30 cases. Mayo Clin Proc 1977, 52 : 477-484.

4. Chusid MJ, Dale DC. Eosinophilic leukemia : remission with vincristine and hydroxyurea. Am J Med 1975, $59:$ 297-300.

5. Chusid MJ, Dale DC, West BC, Wolff SM. The hypereosinophilic syndrome : analysis of fourteen cases with review of the literature. Medicine 1975, 54 : 1-27.

6. Dorfman LJ, Ransom BR, Forno LS, Kelts A. Neuropathy in the hypereosinophilic syndrome. Muscle \& Nerve 1983, $6: 291-298$

7. Dyck PJ, Benstead TJ, Conn DL, Stevens JC, Windebank AJ, Low PA. Non-ᄀ systemic vasculitic neuropathy. Brain 1987, 110:843-854.

8. Even P, Sors H, Venet A, Dennewald G, Reynald P. Angéite granulomateuse allergique de Churg-Strauss, granulomatose de Wegener et vascularites pulmonaires apparentées. In Maladies Systémiques Paris; Flammarion 1986, p 446-483. 
9. Fauci AS, Harley JB, Roberts WC, Ferrans VJ, Gralnick HR, Bjornson BH. The idiopathic hypereosinophilic syndrome: clinical, pathophysiologic and therapeutic considerations. Ann Intern Med 1982, 97 : 78-92.

10. Godeau P, Herreman G, de Saint-Maur P, Guillevin L. Périartérite noueuse et autres angéites nécrosantes. J Mal Vasc (Paris) 1977, 2 239-276.

11. Grisold W, Jellinger K. Multifocal neuropathy with vasculitis in hypereosinophilic syndrome : an entity or drug-induced effect? J Neurol 1985, 231 : 301-306.

12. Hardy WE, Anderson RE. The hypereosinophilic syndromes. Ann Intern Med 1968, 68 : 1220-1229.

13. Kazmierowski LJ, Chusid MJ, Parrillo JE, Fauci AS, Wolff SM. Dermatologic manifestations of the hypereosinophilic syndrome. Arch Dermatol 1978, 114 : 531-535.

14. Marolda M, Orefice G, Barbieri F, Striano S, Camporeale FS, Santagelo R, Catalano A, Crisci C, Ragno M, Cioffi M, DeMattia G. The idiopathic hypereosinophilic syndrome: clinical, electrophysiologic and histologic study of a case. CI Neuropathol 1988, 7:186 (abstr).

15. McCluskey RT, Fienberg R. Vasculitis in primary vasculitides, granulomatoses, and connective tissue diseases. Hum Pathol 1983, 14 : 305-315.

16. Monaco S, Lucci B, Laperchia N, Tezzon F, Curro-Dossi B, Nardelli E, Giannini G, Rizzuto N. Polyneuropathy in hypereosinophilic syndrome. Neurology 1988, 38 : 494-496.

17. Moore PM, Cupps TR. Neurological complications of vasculitis. Ann Neurol 1983, 14: 155-167.

18. Moore PM, Harley JB, Fauci AS. Neurological dysfunction in the idiopathic hypereosinophilic syndrome. Ann Inter Med 1985, 102 : 109-114.

19. Samoszuk MK, Nathwani BN, Lukes RJ. Extensive deposition of eosinophil peroxidase in Hodgkin's and non-Hodgkin's lymphomas. Am J Pathol 1986, 125 : 426-429.

20. Spry CJF, Davis J, Tai PC, Olsen EGJ, Oakley CM, Goodwin JF. Clinical features of fifteen patients with the hypereosinophilic syndrome. Q J Med 1983, 52 : 1-22.

21. Vital A, Vital C. Polyarteritis nodosa and peripheral neuropathy: ultrastructural study of 13 cases. Acta Neuropathol (Berlin) 1985, 67 : 136-141.

22. Weaver DF, Heffernan LP, Purdy RA, Ing VW. Eosinophil-induced neurotoxicity: axo-ᄀ nal neuropathy, cerebral infarction, and dementia. Neurology 1988, 38:144-146.

23. Wees SJ, Sunwood IN, Oh SJ. (1981) Sural nerve biopsy in systemic necrotizing vasculitis. Am J Med 1981, 71 : 525-532.

24. Wichman A, Buchthal F, Pezeshkpour GH, Fauci AS. Peripheral neuropathy in hypereosinophilic syndrome. Neurology 1985, $35: 1140-1145$. 